\title{
KAJIAN FEMINISME DALAM CERITA RAKYAT SI BORU NAITANG
}

\section{Oleh}

\section{Jonner P Naibaho (Naibahojonner8@gmail.com)}

\section{Dr. M. Oky Fardian G, M. Hum.}

Penelitian ini bertujuan untuk memperoleh nilai feminisme dalam cerita rakyat $\mathrm{Si}$ Boru Naitang. Sastra adalah suatu kegiatan yang bersifat seni kreatif yang bisa dihubungkan dengan ilmu lain seperti ilmu bahasa dan sosial, baik dalam sastra lisan dan tulisan. Peran sastra dalam pembentukan karakter bangsa tidak hanya didasarkan pada nilai yang terkandung di dalamnya.Pembelajaran sastra yang bersifat apresiatif pun sarat dengan pendidikan karakter.Kegiatan membaca, mendengarkan, dan menonton karya sastra pada hakikatnya menanamkan karakter tekun, berpikir kritis, dan berwawasan luas.Karya sastra memiliki hubungan timbal balik dengan masyarakat dan tidak bisa dipisahkan dengan nilainilai yang ada dalam masyarakat.Karya sastra juga berjalan bersama dengan perkembangan zaman di masyarakat, sehingga suatu karya sastra ciptaan seseorang merupakan bagian dari masyarakat. Jenis penelitian yang dipakai penulis adalah metode deskriptif kualitatif. Teknik pengumpulan data yang digunakan agar memperoleh data secara mendetail adalah berupa gambar dan dialog yang diperoleh dari catatan hasil rekaman wawancara. Tujuan penelitian ini adalah untuk mengetahui nilai feminisme dalam cerita rakyat Si Boru Naitang. Penelitian ini menggunakan tehnik rekam dan menggunakan metode kualitatif deskriptif.

Kata kunci: Nilai Feminisme, Cerita Rakyat, Karya Sastra

\section{PENDAHULUAN}

Sastra adalah suatu kegiatan yang bersifat seni kreatif yang bisa dihubungkan dengan ilmu lain seperti ilmu bahasa dan sosial, baik dalam sastra lisan dan tulisan. Karya sastra memiliki hubungan timbal balik dengan masyarakat dan tidak bisa dipisahkan dengan nilai-nilai yang ada dalam masyarakat.Karya sastra juga berjalan bersama dengan perkembangan zaman di masyarakat, sehingga suatu karya sastra ciptaan seseorang merupakan bagian dari 
masyarakat.Sastra lisan telah bertahan cukup lama dalam mengiringi sejarah bangsa Indonesia dan menjadi semacam ekspresi estetik tiap-tiap daerah dan suku yang tersebar diseluruh nusantara.Sastra lisan penyampaiannya dari mulut ke mulut yang merupakan warisan turun temurun dan merupakan nilai-nilai luhur yang harus dikembangkan misalnya mitos, legenda, dongeng, dan lain-lain. Pada dasarnya isi sebuah karya sastra memuat perilaku manusia melalui karakter tokoh-tokoh cerita.Sangat beragam perilaku manusia yang bisa dimuat dalam cerita.Kadang-kadang hal ini terjadi perulangan jika diamati secara cermat.Pola atau keterulangan inilah yang ditangkap sebagai fenomena dan seterusnya diklasifikasikan ke dalam kategori tertentu seperti gejala kejiwaan, sosial, dan masyarakat.Sebagai misal perilaku yang berhubungan gejala kejiwaan yaitu fenomena frustrasi atau kekecewaan (anxienty). Perempuan hanya memiliki sedikit pengaruh dalam masyarakat atau bisa dikatakan tidak memiliki hak pada wilayah-wilayah umum dalam masyarakat.Pada era sebelum gerakan feminisme muncul hak-hak wanita begitu dibatasi.Partisipasi wanita dianggap tidak diperlukan.Kaum laki-laki selalu mendominasi dalam ranah apapun.Kaum wanita tidak diperbolehkan menempun pendidikan.Karena kaum wanita dianggap hanya perlu mengurus keluarga jadi tidak perlu berpendidikan tinggi.Dalam hal perekonomian pun wanita tidak diperbolehkan memainkan perannya seperti yang dilakukan kaum laki-laki.Hal ini tentunya menimbulkan kecemburuan sosial terhadap kaum laki-laki. Wanita dianggap makhluk yang selalu bergantung pada laki-laki dan tidak bisa mandiri. Sastra lisan adalah karya yang penyebarannya disampaikan dari mulut ke mulut secara turun-temurun,Oleh karena penyebarannya dari mulut ke mulut, banyak sastra lisan yang memudar karena tidak dapat bertahan.Selain keterbatasan memori manusia dalam mengingat, perkembangan teknologi yang semakin canggih ikut menggeser sastra lisan yang pernah ada, termasuk sastra lisan masyarakat.Batak Toba yang memiliki nilai budaya tinggi, yang seharusnya dapat dijaga kelestariannya.Cerita rakyat "Si Boru Naitang” merupakan salah satu diantara sastra lisan Batak Toba.

\section{METODE PENELITIAN}

Metode penelitian adalah ilmu yang mempelajari tentang jalan yang dilewati untuk mencapai suatu pemahaman, serta penelitian memiliki tujuan, maksudnya kegiatan penelitian ini tidak dapat terlepas dari kerangka tujuan pemecahan permasalahan , walaupun penelitian tidak memberikan jawaban langsung terhadap permasalahan yang diteliti akan tetapi hasilnya harus 
mempunyai konstribusi dalam usaha pemecahan permasalahan tersebut. Sudaryanto (1998:2) "Metodologi adalah cara melakukan sesuatu dengan menggunakan pikiran secara seksama untuk mencapai suatu tujuan. Penelitian adalah suatu kegiatan untuk mencari, mencatat, merumuskan, dan menganalisis sampai dengan menyusun laporan.

Metode yang digunakan dalam penelitian ini adalah metode deskriptif kualitatif.

Metode Deskriptif Kualitatif menurut Ismail, (2009:7) "sebagai suatu pendekatan atau penelusuran untuk mengeksplorasi dan memahami suatu gejala sentral"."Tujuan dari penelitian ini adalah mengungkap fakta, keadaan, fenomena, variabel dan keadaan yang terjadi saat penelitian berjalan dan menyuguhkan apa adanya" (Ismail, 2009:9). Data yang dikumpulkan berupa gambar dan dialog yang diperoleh dari catatan hasil rekaman wawancara. Wawancara adalah perolehan informasi melalui tanya jawab yang dilakukan antara peneliti dan narasumber, sehingga dapat diperoleh suatu hasil akhir dalam suatu topik tertentu. Metode deskriptif tidak berhubungan dengan angka ataupun rumus.

\section{Hasil Penelitian}

\section{a. Jenis-jenis Feminisme dalam Cerita Rakyat Siboru Naitang.}

Berdasarkan hasil penelitian melalui teknik pengumpulan data yaitu teknik dasar simak dengan teknik lanjutan simak catat yang membantu penelitian, maka diperoleh hasil penelitian sebagai berikut:

a. Feminisme Liberal

Dari masa kanak-kanak hingga dewasa mereka selalu bersama baik mengembala maupun mencari kayu baka, kebersamaan mereka menumbuhkan rasa cinta satu sama lain.

Dalam kalimat ini, mengandung sifat bahwa feminisme Liberal memandang wanita perlu diperjuangkan sepenuhnya sama dengan laki-lakibaik itu hak suara, pendidikan maupun kesamaan dalam hukum.

Karena Si Boru Naitang sedang mengandung, maka pihak keluarga Naibaho pun memutuskan untuk menunggu sampai Si Boru Naitang melahirkan anaknya. Setelah tiba waktunya, lahirlah seorang anak laki-laki dari Si Boru Naitang anak dari Inar Naiborngin, dan anak itupun dirawat dan dibesarkan oleh kakeknya Naibaho Hutaparik, dan bertempat tinggal di Pangururan. 
Dalam kalimat ini, mengandung sifat bahwa feminisme Liberal memandang wanita perlu diperjuangkan sepenuhnya sama dengan laki-laki baik itu hak suara, pendidikan maupun kesamaan dalam hukum.

b. Feminisme Anarkis

Karena sering di siksa dan dianiaya akhirnya dia membuat tekad harus pisah dengan suaminya, maka disusunlah sebuah rencana .Mengapa dia bersikap seperti itu?.

Dalam kalimat ini, mengandung sifat bahwa Feminisme Anarkis lebih bersifat sebagai suatu paham politik, dan sistim patriaki dominasi lelaki adalah sumber permasalahan yang sesegera mungkin harus dihancurkan.

Pada saat Sinaga tertidur pulas, entah apa merasuki pikiran Si Boru Naitang, hingga dia mencabik-cabik tubuh suaminya itu,kemudian membuang jasad suaminya kelembah hutan Uruk Bolon tersebut.

Dalam kalimat ini, mengandung sifat bahwa Feminisme Anarkis lebih bersifat sebagai suatu paham politik, dan sistim patriaki dominasi lelaki adalah sumber permasalahan yang sesegera mungkin harus dihancurkan.

c. Feminisme Radikal

Lama kelamaan sikap anak Raja Sinagapun berubah dan sering menjadi kasar dan akhirnya dia mulai mau menyiksa maupun menganiaya, tetapi semua itu ditahan sendiri karena dia yang memilih.

Dalam kalimat ini, mengandung sifat bahwa feminisme radikal beranggapan bahwa penguasaan fisik perempuan oleh laik-laki.Penindasan terhadap perempuan menyebabkan korbannya sangat menderita secara kuanitatif dan kualitatif dan mengganggap bahwa hal tersebut sudah merupakan suatu kewajaran dan alami.

Raja Siahaan Naibaho bersumpah dihadapan semua sanak saudaranya, "bahwa dia tidak pernah memiliki anak yang bernama Inar Naiborngin, dan mulai saat ini tidak ada lagi yang menyebut dan mengingat namanya dimanapun berada. Dia harus keluar dari 
kampung malam ini, dan dia tidak boleh mengakui bahwa dia marga Naibaho kemanapun dia pergi"

Dalam kalimat ini, mengandung sifat bahwa feminisme radikal beranggapan bahwa penindasan terhadap perempuan adalah bentuk penindasan yang paling sulit untuk dihapuskan oleh suatu undang- undang atau suatu perubahan sosial seperti yang terjadai dalam kasus penghapusan pengkelasan dari keluarga atau masyarakat.

\section{d. Feminisme Posmodern}

Sebelum Si Boru Naitang menerima hukuman, Si Boru Naitang mendapat pertolongan dari Bapak Udanya Naibaho Sidauruk untuk mengasingkan Si Boru Naitang kedalam sebuah Goa agar tidak diketahui warga bahwa Si Boru Naitang telah hamil dari saudara kembarnya. Karena Si Boru Naitang sedang mengandung, maka pihak keluarga Naibaho pun memutuskan untuk menunggu sampai Si Boru Naitang melahirkan anaknya

Dalam kalimat ini, mengandung sifat bahwa feminisme posmodern mengatakan dengan curiga setiap pemikiran feminis yang berusaha memberikan suatu penjelasan tertentu mengenai penyebab opresi terhadap perempuan atau langkah untuk mencapai kebebasan.

Si Boru Naitang tidak menyangkal dan mengakui bahwa dia yang telah membunuh suaminya karena menurutnya kejujuranya akan memberikan maaf bagi dirinya. Beginilah jawaban dari pihak perempuan (Naibaho) kepada pihak marga Sinaga, "memang benar, kami akan memberikan atas perbuatan putri kami, hukuman yang tidak akan terbayarkan, akan kami tenggelamkan Si Boru Naitang ke danau. Sebelum Si Boru Naitang menerima hukuman, Si Boru Naitang mendapat pertolongan dari Bapak Udanya Naibaho Sidauruk untuk mengasingkan Si Boru Naitang kedalam sebuah Goa agar tidak diketahui warga bahwa Si Boru Naitang telah hamil dari saudara kembarnya.

Dalam kalimat ini, mengandung sifat bahwa feminisme posmodern mengatakan dengan curiga setiap pemikiran feminis yang berusaha memberikan suatu penjelasan tertentu mengenai penyebab opresi terhadap perempuan atau langkah untuk mencapai kebebasan.

e. Feminisme Marxis 
Dari masa kanak-kanak hingga dewasa mereka selalu bersama baik mengembala maupun mencari kayu baka, kebersamaan mereka menumbuhkan rasa cinta satu sama lain.

Dalam kalimat ini, mengandung sifat bahwa Feminisme Marxis menggangap negara bersifat kapitalis yakni menggangap bahwa negara bukan hanya sekedar intuisi tetapi juga perwujudan dari interaksi atau hubungan sosial dan jika perempuan terjun dalam pasar tenaga kerja dan melakukan pekerjaan yang membosankan- dan melakukan kesalahan maka memperoleh upah yang lebih rendah dibanding dengan laki-laki.

Betapa terkejutnya Si Boru Naitang dan Inar Naiborngin mendengar kabar bahwa dia akan dinikahkan ayahnya dengan anak Raja Ompu Palti Sinaga yang tinggal di Huta Urat. Walaupun tidak pernah bertemu sebelumnya dengan terpaksa Si Boru Naitang menyetujui pernikahan itu, walaupun hati dan pikirannya hanya kepada saudara kembarnya tersebut.

Dalam kalimat ini, mengandung sifat bahwa Feminisme Marxis menggangap negara bersifat kapitalis yakni menggangap bahwa negara bukan hanya sekedar intuisi tetapi juga perwujudan dari interaksi atau hubungan sosial dan jika perempuan terjun dalam pasar tenaga kerja dan melakukan pekerjaan yang membosankan dan melakukan kesalahan maka memperoleh upah yang lebih rendah dibanding dengan laki-laki.

Tidak lama setelah melahirkan, hukuman akan perbuatan Si Boru Naitang pun harus dilaksanakan. Raja Naibaho mengikat batu ke tubuh Si Boru Naitang kemudian dia digulingkan ke dalam danau, akan tetapi dia tetap mengapung dan menangis melihat anaknya Sitindaon. Keesokan harinya dia diikat lagi dengan batu yang lebih besar tapi tetap saja mengapung. Kemudian Si Boru Naitang berkata, “ bapak, aku sudah letih yang kalian tenggelamkan, dan selalu tertekan tiap hari.

Dalam kalimat ini mengandung sifat bahwa Feminisme Marxis menggangap negara bersifat kapitalis yakni menggangap bahwa negara bukan hanya sekedar intuisi tetapi juga perwujudan dari interaksi atau hubungan sosial dan jika perempuan terjun dalam pasar tenaga kerja dan melakukan pekerjaan yang membosankan- dan melakukan kesalahan maka memperoleh upah yang lebih rendah dibanding dengan laki-laki. 


\section{f. Feminisme Sosial}

"bahwa dia tidak pernah memiliki anak yang bernama Inar Naiborngin, dan mulai saat ini tidak ada lagi yang menyebut dan mengingat namanya dimanapun berada. Dia harus keluar dari kampung malam ini, dan dia tidak boleh mengakui bahwa dia marga Naibaho kemanapun dia pergi”. (pada masa itu tidak ada hukum yang melarang membunuh seseorang yang tidak memiliki marga ataupun menjadikannya sebagai budak).

Dalam kalimat ini, mengandung sifat bahwa Feminisme Sosial mengganggap bahwa kehidupan perempuan dalam masyarakat kapitalistik bukan satu-satunya penyebab keterbelakangan pada perempuan, banyak lainnya seperti salah satunya kehidupan masyarakat yang kapitalistik.

Nilai feminisme Sering digambarkan dengan mata, hati dan tindakan yang melihat, menyadari, mengalami adanya penindasan, diskriminasi yang terjadi pada perempuan, mempertanyakan, menggugat dan mengambil aksi untuk mengubah kondisi tersebut. Feminisme dengan demikian berpihak pada perempuan, pada mereka yang ditindas, diskriminasi, dieksplorasi dan diabaikan suatu perangkat keyakinan ataupun perasaan yang diyakini sebagai suatu identitas yang memberikan corak khusus kepada pola pemikiran, perasaan, ketertarikan maupun perilaku

Karena hukum terhadap perempuan lebih besar dari hukuman terhadap laki-laki maka Raja Naibaho harus mengiklaskan hukuman yang setimpal terhadap putrinya

Raja Naibaho mengikat batu ke tubuh Si Boru Naitang kemudian dia digulingkan ke dalam danau, akan tetapi dia tetap mengapung dan menangis melihat anaknya Sitindaon. Keesokan harinya dia diikat lagi dengan batu yang lebih besar tapi tetap saja mengapung.

Si Boru Naitang meminta agar di ikatkan sebuah lesung kebadannya, kemudian diapun berjalan ke danau itu hingga akhirnya dia tenggelam dan tak terlihat lagi.Dan tempat itu menjadi tempat persembahan hingga saat ini.

\section{b. Jenis-jenis Feminisme dalam Cerita Rakyat Siboru Naintang.}


Pembahasan ini akan mendeskripsikan hasil penelitian berupa kalimat yang terdapat pada deskripsi data dengan menggunakan teori feminisme. Deskripsi jenisjenis dan nilai nilai tersebut akan diuraikan secara berkesinambungan sesuai dengan deskripsi data. Berikut pembahasan terhadap data-data tersebut.

a. Feminisme Liberal

Dari masa kanak-kanak hingga dewasa mereka selalu bersama baik mengembala maupun mencari kayu baka, kebersamaan mereka menumbuhkan rasa cinta satu sama lain.

Dalam kalimat ini, mengandung sifat bahwa feminisme Liberal memandang wanita perlu diperjuangkan sepenuhnya sama dengan laki-laki baik itu hak suara, pendidikan maupun kesamaan dalam hukum. Faktanya kebersamaan boruNaitang dengan saudaranya memberikan dampak kenyaman sehingga saling menaruh hati satu sama lain, saudaranya tidak membedakan status boru Naitang di keluarga. Dari beberapa saudaranya, kasih sayang inar Naiborgin lebih besar terhadap Boru Naitang.

Karena Si Boru Naitang sedang mengandung, maka pihak keluarga Naibaho pun memutuskan untuk menunggu sampai Si Boru Naitang melahirkan anaknya. Setelah tiba waktunya, lahirlah seorang anak laki-laki dari Si Boru Naitang anak dari Inar Naiborngin, dan anak itupun dirawat dan dibesarkan oleh kakeknya Naibaho Hutaparik, dan bertempat tinggal di Pangururan.

Dalam kalimat ini, mengandung sifat bahwa feminisme Liberal memandang wanita perlu diperjuangkan sepenuhnya sama dengan laki-laki baik itu hak suara, pendidikan maupun kesamaan dalam hukum. faktanya Ayah Siboru Naitang memberikan kesempatan kepada Boru Naitang untuk menunggu sampai anaknya Lahir, namun hukuman akan tetap dijalankan tanpa adanya belas kasihan.

b. Feminisme Anarkis 
Karena sering di siksa dan dianiaya akhirnya dia membuat tekad harus pisah dengan suaminya, maka disusunlah sebuah rencana .Mengapa dia bersikap seperti itu?.

Dalam kalimat ini, mengandung sifat bahwa Feminisme Anarkis lebih bersifat sebagai suatu paham politik, dan sistim patriaki dominasi lelaki adalah sumber permasalahan yang sesegera mungkin harus dihancurkan. Faktanya seharusnya Keberadaan sosok perempuan lebih dihargai di masyarakat terutama di tengah keluarga, namun karena perbedaan Gender status perempuan lebih rendah dan laki-laki lebih mudah untuk menindas, seperti yang dilakukan suami Si Boru Naitang yang selalu menyiksa istrinya sehingga muncul niat seorang perempuan( Boru Naitang) untuk membuat rencana jahat dengan tujuan membebaskan dirinya dari penyiksaan.

Pada saat Sinaga tertidur pulas, entah apa merasuki pikiran Si Boru Naitang, hingga dia mencabik-cabik tubuh suaminya itu,kemudian membuang jasad suaminya kelembah hutan Uruk Bolon tersebut.

Dalam kalimat ini, mengandung sifat bahwa Feminisme Anarkis lebih bersifat sebagai suatu paham politik, dan sistim patriaki dominasi lelaki adalah sumber permasalahan yang sesegera mungkin harus dihancurkan. Artinya Keputusan Naitang untuk membunuh suaminya dengan cara mencabik- cabik suaminya membuatnya lebih bebas namun dirinya tidak memandang jauh apa yang terjadi dengan nasibnya kedepannya.

c. Feminisme Radikal

Lama kelamaan sikap anak Raja Sinagapun berubah dan sering menjadi kasar dan akhirnya dia mulai mau menyiksa maupun menganiaya, tetapi semua itu ditahan sendiri karena dia yang memilih.

Dalam kalimat ini, mengandung sifat bahwa feminisme radikal beranggapan bahwa penguasaan fisik perempuan oleh laik-laki.Penindasan terhadap perempuan menyebabkan korbannya sangat menderita secara kuantitatif dan kualitatif dan mengganggap bahwa hal tersebut sudah merupakan suatu kewajaran dan alami.Artinya 
Keberadaan Si Boru Naitang di tengah keluarga nya semakin sulit, suaminya selalu berusaha menyakitinya, penguasaan sesecara fisik.Dominasi laki-laki dalam sistem patriarki membuat kekerasan yang menimpa perempuan, seperti kekerasan dalam rumah tangga.

Raja Siahaan Naibaho bersumpah dihadapan semua sanak saudaranya, "bahwa dia tidak pernah memiliki anak yang bernama Inar Naiborngin, dan mulai saat ini tidak ada lagi yang menyebut dan mengingat namanya dimanapun berada. Dia harus keluar dari kampung malam ini, dan dia tidak boleh mengakui bahwa dia marga Naibaho kemanapun dia pergi”

Dalam kalimat ini, mengandung sifat bahwa feminisme radikal beranggapan bahwa penindasan terhadap perempuan adalah bentuk penindasan yang paling sulit untuk dihapuskan oleh suatu undang- undang atau suatu perubahan sosial seperti yang terjadai dalam kasus penghapusan pengkelasan dari keluarga atau masyarakat.Dalam hal ini perbedaan kekerasan secara mental juga terjadi terjadi, bahwa Siboru Naitang akan diasingkan dari keluarga, bahkan dianggap tidak keluarganya lagi atau putrinya lagi (orang asing) dan nama Si Boru Naitang sekalipun akan dihapuskan dan tidak akan ada yang megingat dimanapun.

d. Feminisme Posmodern

Sebelum Si Boru Naitang menerima hukuman, Si Boru Naitang mendapat pertolongan dari Bapak Udanya Naibaho Sidauruk untuk mengasingkan Si Boru Naitang kedalam sebuah Goa agar tidak diketahui warga bahwa Si Boru Naitang telah hamil dari saudara kembarnya. Karena Si Boru Naitang sedang mengandung, maka pihak keluarga Naibaho pun memutuskan untuk menunggu sampai Si Boru Naitang melahirkan anaknya

Dalam kalimat ini, mengandung sifat bahwa feminisme posmodern mengatakan dengan curiga setiap pemikiran feminis yang berusaha memberikan suatu penjelasan tertentu mengenai penyebab opresi terhadap perempuan atau langkah untuk mencapai kebebasan. Penindasan perempuan diawali pada saat perturan simbolis yang diekspresikan melalui bahasa dan cara berpikir. Faktanya Si Boru Naitang awalnya 
mendapat pertolongan dari Pamannya Naibaho, karena diketahui bahwa Si Boru Naitang sedang mengandung, seharusnya keadaan Boru Naitang yang sedang hamil memberikan belas kasihan namun nyata nya peraturan simbolis terhadap perempuan tetap harus dijalankan.

Si Boru Naitang tidak menyangkal dan mengakui bahwa dia yang telah membunuh suaminya karena menurutnya kejujuranya akan memberikan maaf bagi dirinya. Beginilah jawaban dari pihak perempuan (Naibaho) kepada pihak marga Sinaga, "memang benar, kami akan memberikan atas perbuatan putri kami, hukuman yang tidak akan terbayarkan, akan kami tenggelamkan Si Boru Naitang ke danau. Sebelum Si Boru Naitang menerima hukuman, Si Boru Naitang mendapat pertolongan dari Bapak Udanya Naibaho Sidauruk untuk mengasingkan Si Boru Naitang kedalam sebuah Goa agar tidak diketahui warga bahwa Si Boru Naitang telah hamil dari saudara kembarnya.

Dalam kalimat ini, mengandung sifat bahwa feminisme posmodern mengatakan dengan curiga setiap pemikiran feminis yang berusaha memberikan suatu penjelasan tertentu mengenai penyebab opresi terhadap perempuan atau langkah untuk mencapai kebebasan.Artinya Seharusnya Kejujuran Si Boru Naitang memberi kebebasan, namun hukuman tetap berjalan. perempuan mengalami kesulitan dalam pengidentifikasian diri terhadap ayahnya

e. Feminisme Marxis

Dari masa kanak-kanak hingga dewasa mereka selalu bersama baik mengembala maupun mencari kayu baka, kebersamaan mereka menumbuhkan rasa cinta satu sama lain.

Dalam kalimat ini, mengandung sifat bahwa Feminisme Marxis menggangap negara bersifat kapitalis yakni menggangap bahwa negara bukan hanya sekedar intuisi tetapi juga perwujudan dari interaksi atau hubungan sosial dan jika perempuan terjun dalam pasar tenaga kerja dan melakukan pekerjaan yang membosankan- dan melakukan kesalahan maka memperoleh upah yang lebih rendah dibanding dengan laki-laki. Seharusnya sistem kelas bertanggungjawab terhadap diskriminasi fungsi dan status tidak 
membedakan, hingga dewasa, Siboru Naitang tetap bekerja, seperti apa yang dilakukan laki-laki.

Betapa terkejutnya Si Boru Naitang dan Inar Naiborngin mendengar kabar bahwa dia akan dinikahkan ayahnya dengan anak Raja Ompu Palti Sinaga yang tinggal di Huta Urat. Walaupun tidak pernah bertemu sebelumnya dengan terpaksa Si Boru Naitang menyetujui pernikahan itu, walaupun hati dan pikirannya hanya kepada saudara kembarnya tersebut.

Dalam kalimat ini, mengandung sifat bahwa Feminisme Marxis menggangap negara bersifat kapitalis yakni menggangap bahwa negara bukan hanya sekedar intuisi tetapi juga perwujudan dari interaksi atau hubungan sosial dan jika perempuan terjun dalam pasar tenaga kerja dan melakukan pekerjaan yang membosankan dan melakukan kesalahan maka memperoleh upah yang lebih rendah dibanding dengan laki-laki. Seorang perempuan tidak dapat memutuskan pilihannya sendiri.Eksitensi sosial mencuatkan isu bahwa setiap perempuan harus menuruti semua perintah karena seprti yang dilakukan Si Boru Naintang yang menerima perjodohan.

Tidak lama setelah melahirkan, hukuman akan perbuatan Si Boru Naitang pun harus dilaksanakan. Raja Naibaho mengikat batu ke tubuh Si Boru Naitang kemudian dia digulingkan ke dalam danau, akan tetapi dia tetap mengapung dan menangis melihat anaknya Sitindaon. Keesokan harinya dia diikat lagi dengan batu yang lebih besar tapi tetap saja mengapung. Kemudian Si Boru Naitang berkata, " bapak, aku sudah letih yang kalian tenggelamkan, dan selalu tertekan tiap hari.

Dalam kalimat ini mengandung sifat bahwa Feminisme Marxis menggangap negara bersifat kapitalis yakni menggangap bahwa negara bukan hanya sekedar intuisi tetapi juga perwujudan dari interaksi atau hubungan sosial dan jika perempuan terjun dalam pasar tenaga kerja dan melakukan pekerjaan yang membosankan- dan melakukan kesalahan maka memperoleh upah yang lebih rendah dibanding dengan laki-laki. Bahkan setelah Siboru Naitang melahirkan sekalipun tidak ada ampun terhadapnya, keluarganya tidak memikirkan nasib anak yang dilahirnnya, karena hanya melihat relasi kekeluargaan 
yang semata-mata eksploitasi kapitalisme, dimana perempuan memberikan tenaganya secara gratis.

f. Feminisme Sosial

"bahwa dia tidak pernah memiliki anak yang bernama Inar Naiborngin, dan mulai saat ini tidak ada lagi yang menyebut dan mengingat namanya dimanapun berada. Dia harus keluar dari kampung malam ini, dan dia tidak boleh mengakui bahwa dia marga Naibaho kemanapun dia pergi”. (pada masa itu tidak ada hukum yang melarang membunuh seseorang yang tidak memiliki marga ataupun menjadikannya sebagai budak).

Dalam kalimat ini, mengandung sifat bahwa Feminisme Sosial mengganggap bahwa kehidupan perempuan dalam masyarakat kapitalistik bukan satu-satunya penyebab keterbelakangan pada perempuan, banyak lainnya seperti salah satunya kehidupan masyarakat yang kapitalistik.Keberadaan Si Boru Naitang Bukan memberi perhatian lebih pada masalah gender, justru berkonsentrasi pada analisis kelas.Karena hukum terhadap perempuan lebih besar dari hukuman baut laki-laki maka Raja Naibaho harus mengiklaskan hukuman yang setimpal terhadap putrinya. Tidak lama setelah melahirkan, hukuman akan perbuatan Si Boru Naitang pun harus dilaksanakan. Perempuan merupakan tokoh utama dalam nilai-nilai feminisme, dan laki-laki sebagai tokoh pendukung.Nilai feminisme Sering digambarkan dengan mata, hati dan tindakan yang melihat, menyadari, mengalami adanya penindasan, diskriminasi yang terjadi pada perempuan, mempertanyakan, menggugat dan mengambil aksi untuk mengubah kondisi tersebut. Feminisme dengan demikian berpihak pada perempuan, pada mereka yang ditindas, diskriminasi, dieksplorasi dan diabaikan suatu perangkat keyakinan ataupun perasaan yang diyakini sebagai suatu identitas yang memberikan corak khusus kepada pola pemikiran, perasaan, ketertarikan maupun perilaku.

Karena hukum terhadap perempuan lebih besar dari hukuman terhadap laki-laki maka Raja Naibaho harus mengiklaskan hukuman yang setimpal terhadap putrinya. Raja Naibaho mengikat batu ke tubuh Si Boru Naitang kemudian dia digulingkan ke dalam danau, akan tetapi dia tetap mengapung dan menangis melihat anaknya Sitindaon. Keesokan harinya dia diikat lagi dengan batu yang lebih besar tapi tetap saja mengapung. 
Si Boru Naitang meminta agar di ikatkan sebuah lesung kebadannya, kemudian diapun berjalan ke danau itu hingga akhirnya dia tenggelam dan tak terlihat lagi.Dan tempat itu menjadi tempat persembahan hingga saat ini.

Ketidaksetaraan gender mengakibatkan hukum dan keadilan timpang. Siboru Naitang yang menerima hukuman atas dirinya seharusnya menjadi pelajaran bagi masyarakat umum pada saat itu.Seharusnya Kejadian Si Boru Naitang memberikan kedudukan dan peran perempuan juga turut terbentuk dengan mengacu pada nilai-nilai yang terkandung dalam ajaran agama dalam sebuah negara.

\section{PENUTUP}

Berdasarkan hasil penenlitian dapat diambil simpulan sebagai berikut:Sejarah pembedaan antara laki-laki dan perempuan terjadi melalui proses sosialisasi, penguatan dan konstruksi sosial kultural, keagamaan, bahkan melalui kekuasaan negara. Berdasarkan jenis -jenis nilai feminisme dalam teori yang dipakai pada penelitian ini, yaitu Feminisme Radikal, Feminisme Anarkis,

Feminisme Radikal, Feminisme Posmodern, Feminisme Marxis dan Feminisme Sosial yang terdapat dalam cerita rakyat. Penulis mengajak masyarakatuntuk melihat sifat feminisme ini dan mencapai kesetaraan hak antara laki-laki dan perempuan tanpa memandang status.Nilai Feminisme tentang keadaan Si Boru Naitang diharapkan dapat memberikan implikasi yang harus saling menghormati hak dan kewajiban orang tanpa diskriminasi ras, agama dan jenis kelamin.Cerita Si Boru Naitang diyakini sebagai identitas yang memberikan corak khusus kepada pola pemikiran, dan tempat bersemayamnya Boru Naitang saat ini diyakini masyarakat Pangururan dijadikan tempat persembahan dan memanjatkan permohonan terutama meminta kesembuhan.

\section{DAFTAR PUSTAKA}

Ahmadi dan Uhbiyati. 1991. Hakekat Nilai. Yogyakarta : Graha ilmu Kridalaksan. 2009. Perempuan dalam Pandangan Feminisme. Yogyakarta: Pustaka Pelajar. Pudentia. 2003. Sifat-sifat Folklore. Jakarta: Penerbit Garudhawaca Sugihastuti dan Suharto. 2002. Menuntut Persamaan Hak. Yogyakarta: Pustaka Widyartama. Tong. 2012. Kaum Feminis . Jakarta: Yayasan Obor Indonesia. 
